Volume 2 Nomor 1, Maret 2020, Halaman 27-38

\title{
PEMBERDAYAAN PETANI DALAM MENGURANGI RESIDU MELALUI PERTANIAN RAMAH LINGKUNGAN DI BPP TAMBUN UTARA, KABUPATEN BEKASI
}

\author{
Oktavia, H.F. ${ }^{\text {) }}$, Susilastuti, D. ${ }^{2)}$, Aditiameri ${ }^{3)}$, Husin, M. ${ }^{4)}$, Tobing, S.ML. ${ }^{5)}$, \\ Rahmayanti, F.D ${ }^{6)}$ \\ ${ }^{1)}$ Fakultas Pertanian, Universitas Borobudur-Jakarta. \\ Email: henita.f.10@gmail.com ${ }^{1}$; darwatisusi@borobudur.ac.id ${ }^{2}$; \\ aditiameri65@yahoo.co.id ${ }^{3}$; sumihar_tobing@borobudur.ac.id ${ }^{4}$; \\ hoeseen@gmail.com ${ }^{5}$ fetty_dwi@borobudur.ac.id ${ }^{6}$
}

\begin{abstract}
Abstrak
Pertanian tradisional menggunakan pupuk kimia dan pestisida yang tinggi untuk jangka panjang berdampak negatif terhadap lingkungan, akibat adanya residu bahan kimia yang mencemari lingkungan. Petani di wilayah binaan Balai Penyuluhan Pertanian (BPP) Tambun Utara, Kabupaten Bekasi, memiliki tanah yang cocok untuk pertanian tanaman pangan, palawija dan hortikultura Dalam produksi pertaniannya masih menggunakan pupuk kimia dan pestisida dengan dosis yang cukup tinggi, tidak tepat takaran, cara, jenis serta frekuensinya. Untuk mengurangi dampak negatif residu pemakaian bahan kimia pertanian terhadap lingkungan dan hasil, yaitu mengganti pupuk kimia dengan pupuk organik, pestisida kimia dengan biopestisida. Pemberdayaan petani bertujuan untuk menambah pengetahuan, pembelajaran dan ketrampilan tentang pemilihan komposisi bahan dasar pembuatan pupuk organik dan biopestisida, pelatihan pembuatannya serta pendampingan cara mengaplikasikan langsung ke lahan pertanian. Metode dan pendekatan yang digunakan adalah penyuluhan dan pendekatan langsung juga pelatihan kepada petani dilengkapi dengan instrumen pre dan post test. Luaran kegiatan PkM (Pengabdian kepada Masyarakat) adalah meningkatnya pemahaman petani terhadap pertanian ramah lingkungan, meningkatnya pengetahuan petani dalam penggunaan pupuk organik dan biopestisida yang dibuat sendiri oleh peserta, serta meningkatnya minat dan motivasi dari petani untuk mengembangkan alternatif pupuk organik dan biopestisida yang sesuai dengan ketersediaan bahan di sekitar dan pola tanam. Dibuktikan setelah penyuluhan terdapat peningkatan aspek pengetahuan sebesar $27,1 \%$, aspek sikap sebesar $19,54 \%$ dan aspek perilaku sebesar $8,9 \%$.
\end{abstract}

Kata Kunci: Pemberdayaan, Residu, Pertanian Ramah Lingkungan, Pupuk Organik, Biopestisida

\begin{abstract}
Conventional agriculture used chemical fertilizers and pesticides for long-term had negative impacts on the environment, due to chemical residues that pollute the environment. Farmers in the area of Agricultural Extension Center (BPP) at North Tambun, Bekasi Regency, have land that is suitable for farming food crops, legume plants and horticulture. The use of chemical fertilizers and pesticides in agricultural production is still quite high until now, and doesn't used exact dose, method, type and frequency. To reduce the negative impact of residues using agricultural
\end{abstract}


chemicals on the environment and yields, by replacing chemical fertilizers with organic fertilizers, chemical pesticides with bio-pesticides. Farmer empowerment aims to increase knowledge, learning and skills regarding the selection of the composition of basic ingredients for making organic fertilizers and biopesticides, manufacturing training and assistance in how to apply directly to agricultural land. The methods and research approach that we use are counseling and direct approach also training for farmers equipped with pre and post test instruments. The outputs of Community Services activities are increasing farmers understanding of environmentally friendly agriculture, increasing farmers knowledge in using organic fertilizers and biopesticides made by participants, and increasing interest and motivation from farmers to develop alternative organic fertilizers and biopesticides that are in accordance with the availability materials around and cropping patterns. It was proven that after counseling there was an increase in the knowledge aspect by $27.1 \%$, the attitude aspect by $19.54 \%$ and the behavioral aspect by $8.9 \%$. Keywords: Empowerment, Residues, Environmentally Friendly Agriculture, Organic Fertilizers, Biopesticides

\section{DOI: https://doi.org/10.31943/abdi.v2i1.21}

\section{A. Pendahuluan}

Kabupaten Bekasi khususnya wilayah Tambun Utara merupakan wilayah pengembangan kawasan padi. Data BPS tahun 2017 menunjukkan bahwa Tambun Utara merupakan sentra padi dan relatif sedikit tanaman hortikultura dan palawija. Luas panen dan produksi untuk tanaman padi di Kabupaten Bekasi tahun 2017 sebesar: 91.945 hektar dengan produksi per hektar dan 573,928 ton (Kementerian Pertanian, 2015 dan BPS Kabupaten Bekasi, 2019).

Saat ini permasalahan yang harus segera diselesaikan di sektor pertanian, Kabupaten Bekasi termasuk juga Kecamatan Tambun Utara adalah menurunnya produktivitas lahan, dan menurunnya produksi padi pada satu luasan lahan. Permasalahan tersebut diperparah dengan adanya konversi lahan pertanian yang subur ke lahan nonpertanian secara besar-besaran untuk membangun fisik dan perekonomian, juga kesalahan kelola lahan pertanian yang menyebabkan kemunduran kesuburan tanah, serta merusak sumberdaya alam.

Paradigma pembangunan pertanian yang cenderung bersifat eksploitasi yang lebih mengutamakan produksi jangka pendek perlu diubah menjadi paradigma pertanian berkelanjutan. Pertanian berkelanjutan merupakan bentuk pemanfaatan sumber daya baik yang dapat diperbaharui maupun sumberdaya yang tidak dapat diperbaharui dengan cara-cara yang ramah lingkungan dan berkelanjutan. Sistem produksi pertanian berkelanjutan lebih mengarah pada pengelolaan pertanian organik yang ramah terhadap lingkungan. Upaya untuk mengaktualisasikan potensi yang dimiliki oleh petani di Tambun Utara diperlukan adanya pemberdayaan petani secara komprehensif. Pemberdayaan petani adalah upaya peningkatan kemampuan petani agar tanggap dan kritis terhadap berbagai perubahan, serta kompeten dan mampu mengakses proses pembangunan untuk mendorong kemandirian yang berkelanjutan. Upaya pemberdayaan petani pada hakekatnya dikaitkan dengan karakteristik sasaran sebagai suatu komunitas yang mempunyai ciri, latar belakang, dan budaya tertentu. 
Budidaya pertanian organik merupakan metode usahatani, melalui pemanfaatan sumberdaya lokal secara intensif dengan sedikit atau tidak menggunakan input luar artinya tanpa menggunakan bahan kimia seperti pupuk dan pestisida kimia. Budidaya pertanian tersebut diharapkan dapat menghasilkan kuantitas dan kualitas produk yang tinggi tanpa merusak lingkungan. Produk pertanian tersebut akan bebas dari kontaminan (pencampuran) bahan kimia seperti pupuk dan pestisida buatan. Lahan pertaniannya juga akan membaik kualitasnya karena tidak adanya unsur yang merusak akibat efek residu bahan kimia.

Kenyataannya, para petani berfikir dua kali untuk melakukan budidaya organik. Sebagian besar petani di daerah Tambun Utara saat ini masih jarang dan enggan menggunakan pupuk organik dengan alasan sulit mendapatkannya, biaya transportasi dan aplikasinya mahal, peningkatan hasil padi tidak cepat terlihat dan tidak signifikan dibandingkan dengan pupuk kimia. Di sisi lain manfaat bahan organik penting bagi kesuburan kimia, fisika, dan biologi tanah, diantaranya: memperbaiki struktur dan permeabilitas tanah, memperbaiki aerasi, meningkatkan kapasitas menahan air tersedia, sebagai buffer kimia untuk mengurangi perubahan pH secara cepat untuk tanah lahan kering. Pada lahan sawah beririgasi peran dan manfaat bahan organik hampir tidak berarti pada perbaikan sifat fisika tanah, karena pengolahan dan pelumpuran tanah akan merusak struktur dan permeabilitas tanah sawah (Mamaril et al. 2009). Demikian juga perbaikan sifat kimia tanah, peran bahan organik hampir tidak ada karena penggenangan lahan sawah dapat meningkatkan $\mathrm{pH}$ tanah mendekati netral. Sedangkan karakteristik tanah di Tambun Uatara tersebut banyak dipengaruhi oleh air, seperti warna kelabu, mengandung banyak karatan, konkresi Fe atau Mn tinggi, tingkat kesuburan tanah relatif rendah dan $\mathrm{pH}$ tanah masam (Kementerian Pertanian, 2015). Kesuburan tanah yang rendah, miskin unsur hara makro dan mikro menyebabkan tingkat kesuburan dan produktivitas tanah menjadi rendah dan pertumbuhan tanaman menjadi terganggu karena proses metabolisme di dalam jaringan tanaman terganggu. Tingkat produktivitas tanah yang rendah dapat ditingkatkan dengan pengelolaan hara terpadu melalui penambahan pupuk anorganik, pengapuran dan bahan organik. Hasil penelitian Suyamto (2017), menyatakan bahwa untuk mencapai hasil padi yang tinggi, penggunaan bahan dan pupuk organik yang dikombinasikan dengan pupuk kimia merupakan tindakan yang bijaksana. Melalui pemberian jumlah dan jenis pupuk yang tepat, pemupukan menjadi lebih efisien dan menguntungkan agar tanaman dapat berproduksi secara optimum dan lingkungan terjaga kelestariannya.

Permasalahan lain yang menghantui petani Tambun Utara adalah menurunnya kuantitas, kualitas dan luas panen padi yang diakibatkan dengan meningkatnya serangan organisme pengganggu tanaman (OPT), seperti: walang sangit, keong mas, penggerek batang, penyakit hawar daun dan penyakit blas dan gagalnya pengendalian secara konvensional.

Hasil penelitian Ningrum (2012) mengatakan 95\% petani Tambun Utara menggunakan pestisida sistemik, hal ini disebabkan adanya kekhawatiran petani terhadap kehilangan hasil panen bila hama dan penyakit menyerang dan tidak dapat dikendalikan. Sedangkan, penggunaan pestisida kimiawi terbukti telah mencemari lingkungan, terutama jika diaplikasikan secara tidak terkendali. Budidaya pertanian yang peduli kelestarian lingkungan dan dampak buruk penggunaan pestisida kimia perlu didukung melalui pengendalian OPT yang didasarkan pada pertimbangan 
ekologi dalam rangka pengelolaan agroekosistem yang ramah lingkungan. Pengendalian OPT dengan mempertimbangkan kelestarian lingkungan memiliki risiko yang kecil, tidak mengakibatkan hama menjadi kebal ataupun resurgensi, serta aman bagi kesehatan manusia dan lingkungan.

Manfaat pengendalian OPT ramah lingkungan adalah untuk meningkatkan produktivitas tanaman secara berkesinambungan, pelestarian lingkungan, keamanan dan keselamatan petani; serta keamanan konsumen. Biopestisida adalah bahan-bahan alami seperti tumbuh-tumbuhan yang berpotensi dapat mengendalikan OPT. Tumbuhan yang biasa digunakan dalam pembuatan biopestisida antara lain mimba, cengkeh, serai wangi, mahoni, dan tumbuhan lainnya. Kombinasi dari tumbuhan-tumbuhan dapat berfungsi: menolak hama, menghasilkan racun, mengganggu siklus pertumbuhan hama, dan mengganggu pencernaan atau merubah perilaku hama.

Secara umum tujuan pemberdayaan adalah memberikan pemahaman, memotivasi sehingga mereka dapat mengubah sikap dan bertindak. Tujuan pengabdian masyarakat ini adalah: 1). Memberikan pemahaman bersama tentang pertanian ramah lingkungan; 2). Mengajak petani agar berpartisipati (bersikap dan bertindak) dalam kegiatan program pemberdayaan pertanian ramah lingkungan guna terwujud sistem pertanian berkelanjutan yang ramah lingkungan yang menghasilkan produk-produk pertanian khususnya bahan pangan bebas residu bahan kimia dan aman bagi kesehatan; 3). Adanya transfer teknologi inovasi pertanian; 4). Memberikan ketrampilan pada petani dalam pembuatan pupuk organik dan biopestisida, menginspirasi petani untuk kreatif dan inovatif memanfaatkan sumber daya sekitar sebagai bahan baku pupuk organik dan biopestisida. Selain itu, melalui kegiatan ini Tim Pengabdian kepada Masyarakat (PKM) Fakultas Pertanian Universitas Borobudur ikut mensosialisasikan teknologi ramah lingkungan untuk mendukung swasembada pangan berkelanjutan yang digalakkan oleh Kementerian Pertanian saat ini.

\section{B. METODE}

Pengabdian kepada masyarakat ini dilaksanakan pada 25 - 26 April 2019 bertempat di Kantor BPP Tambun Utara, Kampung Gabus Gedong, Desa Srimukti, Kecamatan Tambun Utara, Kabupaten Bekasi Jawa Barat. Metode dan pendekatan yang digunakan adalah penyuluhan dan diskusi langsung serta pelatihan kepada petani dilengkapi dengan instrumen pre dan post test. Peserta yang mengikuti pengabdian masyarakat terdiri dari petani padi sebanyak 38 orang bimbingan BPP, penyuluh pertanian dan koordinator penyuluh OPT Kabupaten Bekasi, dosen dan mahasiswa Fakultas Pertanian Universitas Borobudur. Kegiatan pengabdian ini mencakup penyuluhan pada hari pertama dan pelatihan berlangsung pada hari ke dua.

\section{Bahan Dan Alat}

Bahan yang digunakan untuk pelatihan pupuk organik adalah: bonggol pisang, nanas, air kelapa, air cucian beras, gula merah, dan bahan untuk pelatihan biopestisida: daun pepaya, deterjen dan minyak tanah. Alat yang digunakan meliputi: LCD, laptop, spidol, kamera, ember/wadah, drum plastik, pisau, timbangan, corong, kain halus, botol dan selang plastik.

\section{Metode Pelaksanaan}


Pelaksanaan Pengabdian Kepada Masyarakat ini dilakukan dengan metode 1). Penyuluhan, yang dilengkapi dengan Pre-test dan Post-test untuk mengetahui pengetahuan, perilaku atau sikap dan tindakan yang berkaitan pertanian ramah lingkungan. Metode pre-test dan post-test digunakan karena efektif dan ringkas mengukur dan mengevaluasi proses pembelajaran. Pre-test diberikan sebelum penyuluhan untuk mengetahui sejauh mana pengetahuan responden sebelum materi diberikan. Post test diberikan setelah penyuluhan untuk mengetahui pemahaman responden terhadap materi penyuluhan setelah kegiatan dilaksanakan (Costa, 2013 dan Purwanto, 1998 dalam Damayanti, dkk., 2017); dan 2). Pelatihan pembuatan biopestisida dan pupuk hayati. Penyuluhan dan pelatihan ini disampaikan oleh Tim Dosen dan Mahasiswa Fakutas Pertanian Universitas Borobudur Jakarta. Untuk mewujudkan pemberdayaan petani dalam mewujudkan pertanian ramah lingkungan digambarkan dengan konsep pertanian terpadu seperti gambar di bawah ini:

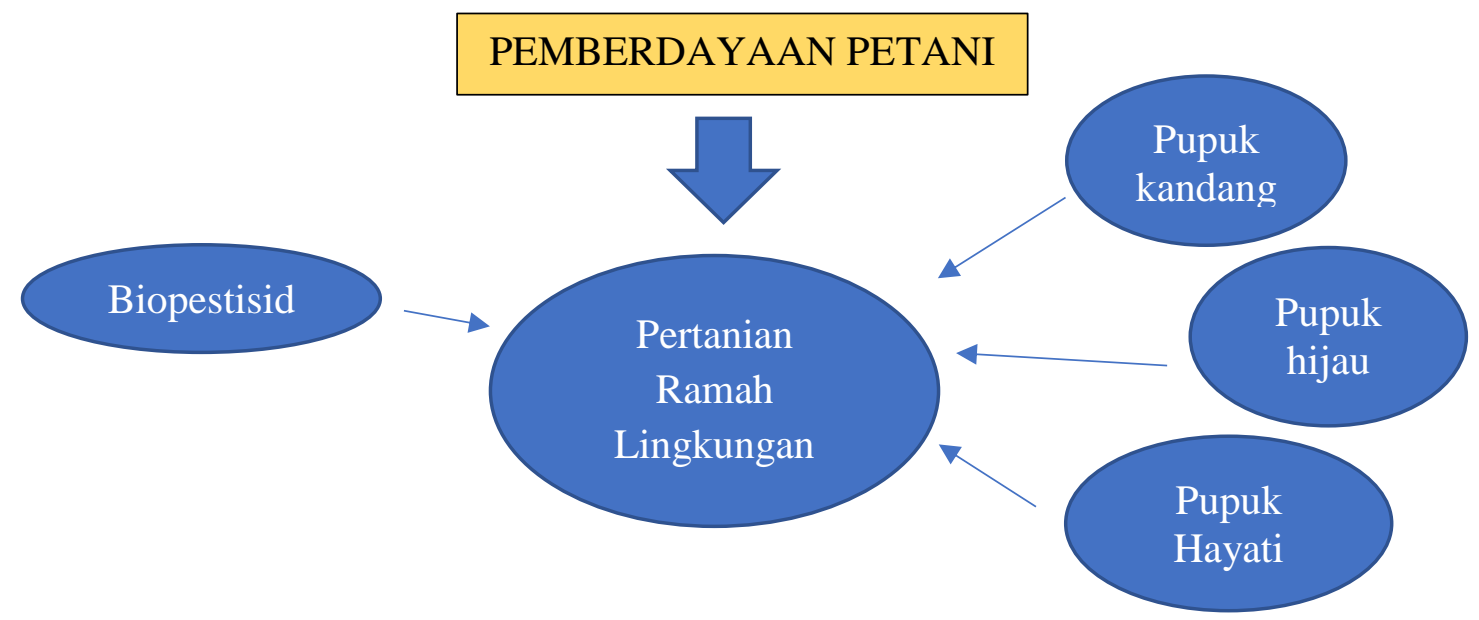

Gambar. 1: Konsep Pemberdayaan Petani Dalam Pertanian Ramah Lingkungan

Materi utama penyuluhan tentang: 1). Bahaya Bahan Kimia Pertanian pada Pertanian ramah lingkungan; 2). Biopestisida pada Pengendalian OPT Padi dan 3). Peran Pupuk Hayati untuk Meningkatkan Hasil Padi. Sedangkan materi pelatihan pembuatan Pupuk Organik yang berbahan baku utama bonggol pisang dan pembuatan biopestisida yang berbahan baku utama daun Pepaya. Adapun tahapan di dalam pelaksanaan pengabdian masyarakat ini:

1. Observasi lapangan untuk kegiatan PKM.

2. Melakukan koordinasi, integrasi, optimalisasi partisipasi, dengan aparat desa dengan melibatkan perguruan tinggi Fakultas Pertanian Universitas Borobudur dan sasaran penyuluhan yaitu petani dan penyuluh pertanian.

3. Menyusun program penyuluhan pertanian ramah lingkungan yang sejalan dengan kebijakan dan program pemerintah.

4. Melakukan diseminasi inovasi dan penerapan teknologi pertanian berupa pembuatan pupuk organik dan biopestisida.

5. Membagikan kuesioner yang berisi tentang karakteristik dan kapasitas petani Tambun Utara menerima pertanian ramah lingkungan.

Melakukan analisis terhadap hasil kuesioner yang telah dilakukan untuk melihat seberapa jauh pemberdayaan petani dalam mengurangi residu melalui pertanian ramah lingkungan. 
Pada kegiatan pengabdian kepada masyarakat ini selaku mitra adalah BPP (Balai Penyuluhan Pertanian) Tambun Utara. Adapun partisipasi yang dilakukan oleh mitra yaitu BPP Tambun Utara yaitu: Mensosialisasikan dan mengumpulkan peserta; Mengikuti kegiatan penyuluhan dan pelatihan; Menyediakan tempat pelatihan dan penyuluhan; Melakukan kreatifitas pembuatan pupuk hayati dan biopestisida; serta memantau petani yang mengplikasikan hasil penyuluhan dan pelatihan.

Pengukuran keberhasilan pengabdian kepada masyarakat dilakukan dengan mengukur peningkatan pemahaman setelah penyuluhan melalui metode pre test dan post test aspek pengetahuan, sikap dan tindakan. Jika terjadi peningkatan yang nyata maka penyuluhan dinyatakan berhasil. Pada kegiatan pelatihan, keberhasilan pelatihan dinyatakan dengan ada tidaknya peserrta yang mengaplikasikan hasil pelatihan, adanya kreatifitas dan inovasi hasil pelatihan yang diaplikasikan akan menambah nilai keberhasilan dari kegiatan pelatihan tersebut.

Untuk melengkapi data deskriptif dan profil peserta, pada kuisioner ditanyakan pula data tambahan tentang nama, usia, pendidikan, lama bertani, luas lahan, produktivitas dan jenis dan takaran pupuk serta pestisida yang dipakai.

\section{HASIL DAN PEMBAHASAN}

Berdasarkan hasil kuesioner diperoleh data rata-rata usia petani antara 46 60 tahun adalah 41,33\%, sedangkan tingkat pendidikan petani SD sampai SMP adalah $80 \%$ dan dikategorikan tingkat pendidikan rendah. Untuk pengalaman bertani dikategorikan rendah (11 - 20 tahun) dengan perolehan 40\%. Rendahnya tingkat pendidikan, pengalaman bertani dan banyaknya petani yang berusia lanjut berdampak terhadap pola pikir petani, sehingga petani Tambun Utara kurang dapat mengadopsi pertanian ramah lingkungan yang berdampak terhadap ekonomi, sosial dan kerusakan ekologi Sebagaian besar petani (lebih dari 95\%) lebih memilih penggunaan bahan kimia (pupuk dan pestisida). Walaupun $90 \%$ petani memiliki luas lahan dengan kategori tinggi $(1,1-4 \mathrm{ha})$, tetapi luas lahan tersebut diperoleh dari tanah warisan.

\section{Penyuluhan}

Materi penyuluhan yang diberikan adalah: 1). Bahaya Bahan Kimia Pertanian pada Pertanian ramah lingkungan. Dijelaskan bahwa Penggunaan pupuk yang berbahan kimia buatan mempunyai keuntungan misalnya jumlah kandungan hara tinggi, lebih cepat tersedia, lengkap dan lebih murah, namun demikian penggunaan dalam waktu yang cukup lama dengan dosis tinggi dapat mengakibatkan adanya residu baik di alam maupun di tanaman atau bahkan dapat mencemari lingkungan. Penggunaan pestisida yang berbahan kimia buatan mempunyai keuntungan memberantas patogen lebih cepat. Namun demikian penggunaan dengan frekuensi tinggi, dosis yang tinggi dan penggunaan yang tidak tepat cara dan volume serta waktu yang tidak tepat dapat menyebabkan keracunan, residu, pencemaran dan resitensi bagi organisme pengganggu tanaman.

Penggunaan bahan kimia organik yaitu bahan kimia yang berasal dari mahkluk hidup. Keuntungannya adalah kandungan haranya lebih lengkap walaupun ketersediaannya lambat. Tidak menyebabkan residu di alam karena akan terurai secara alami. Memperbaiki struktur tanah karena dapat mengaktifkan microorganisme tanah; 2). Biopestisida pada Pengendalian OPT Padi. Dijelaskan bahwa 
biopestisida merupakan salah satu bahan ramah lingkungan yang digunakan untuk menekan dampak negatif penggunaan pestisida kimia, merupakan bahan nabati yang potensial untuk mengendalikan OPT. Penambahan mikroba akan meningkatkan kefektifan fungsinya. Keuntungan biopestisida adalah murah karena bahan melimpah, aman bagi mahluk hidup walaupun dengan penggunaann dosis tinggi, produk yang dihasilkan sehat, tidak meninggalkan residu dan dapat mempertahankan musuh alami (Sri Wahyuni, 2018); dan 3). Peran Pupuk Hayati untuk Meningkatkan Hasil Padi. Pupuk hayati merupakan pupuk yang diberikan kepada tanaman yang mengandung mikroorganisme untuk mendorong pertumbuhan melalui pemenuhan kebutuhan nutrisi tanaman (Anonim, 2011 dalam Maharani et al, 2013). Mikroba tersebut antara lain berfungsi dalam membantu penambatan unsur hara, sebagai antibiotik maupun hormon pertumbuhan. Pupuk hayati sangat direkomendasikan dalam melakukan kegiatan budidaya tanaman, karena jenis pupuk ini terbuat dan atau diperkaya dari bahan-bahan yang tersedia di alam, sehingga kekhawatiran akan pencemaran tanah tidak lagi terjadi. Efektifitas dan efisiensi pemanfaatan pupuk hayati didasarkan atas respon positifnya sehingga selain meningkatkan pertumbuhan juga dapat menghemat biaya pupuk dan penggunaan tenaga kerja.

Penyuluhan dilakukan terhadap petani dan penyuluh pertanian Tambun Utara. Tujuan penyuluhan ini untuk memberikan pengetahuan kepada peserta tentang pertanian ramah lingkungan, dampak dan manfaatnya terhadap produktivitas lahan, lingkungan, dan manusia dan pengenalan tentang pupuk hayati dan biopestisida.

Komunikasi antara narasumber dengan peserta merupakan bukti nyata bahwa para petani menyambut adanya pertanian ramah lingkungan. Setelah materi disampaikan, dilanjutkan dengan tanya jawab dan diskusi. Selama mengikuti kegiatan penyuluhan peserta secara umum sangat menikmati. Petani memiliki motivasi yang tinggi dan mempunyai pengharapan yang sangat positif atas diadakannya kegiatan ini.

Hasil pemetaan tentang pengetahuan, sikap dan perilaku masyarakat tentang pertanian ramah lingkungan sebelum penyuluhan (pre-test) diikuti oleh 38 responden (Gambar 1), sedangkan setelah penyuluhan diikuti oleh 32 orang (posttest) (Gambar 2). Hasil pemetaan adalah sebagai berikut:

1. Sebelum penyuluhan:

Aspek pengetahuan: $60,4 \%$ ya, 26,3\% ragu-ragu, 5,3\% tidak tahu Aspek sikap : $78,9 \%$ setuju, 18,4\% kurang setuju, $2.7 \%$ tidak setuju Aspek perilaku : $\quad 47,4 \%$ ya, 38,8\% ragu-ragu, 15,8\% kadang-kadang

2. Setelah penyuluhan :

Aspek pengetahuan: $87,5 \%$ ya, $12,5 \%$ ragu-ragu, $0 \%$ tidak tahu Aspek sikap : $: 98,44 \%$ setuju, 0,78 kurang setuju, 0,68\% tidak setuju Aspek perilaku $: 56,3 \%$ ya, $28,1 \%$ ragu-ragu, 3,8\% kadang-kadang 


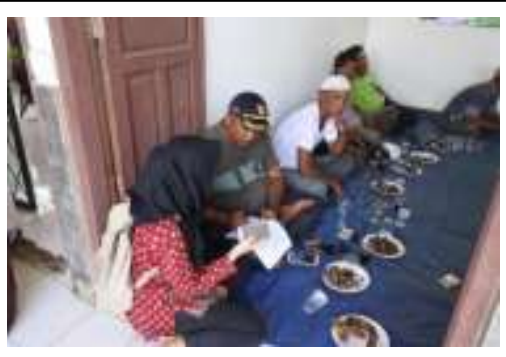

Gambar 1. Kegiatan Pre Test

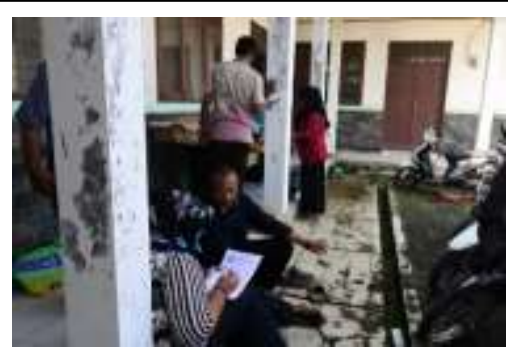

Gambar 2. Kegiatan Post Test

Berdasarkan evaluasi hasil pemetaan di atas bahwa petani Tambun Utara telah mempunyai pengetahuan dan sikap yang cukup tentang pertanian ramah lingkungan namun kurang didalam perilaku atau tindakan nyata dalam melaksanakan pertanian ramah lingkungan. Dengan adanya penyuluhan dan pelatihan telah dapat meningkatkan pengetahuan dan sikap maupun motivasi namun belum dapat meningkatkan perilaku. Masih adanya keragu-raguan petani dalam bertindak kemungkinan disebabkan belum adanya percontohan dimana penggunaan pupuk organik, biopestisida dan sistem pertanian ramah lingkungan akan meningkatkan kuantitas dan kualitas hasil yang signifikan. Menurut Balingtan (2018), efek penggunaan pupuk organik dan biopestisia memang tidak nampak cepat tergantung tingkat pencemaran lahan dan perlu adanya bioremediasi. Perlu adanya percontohan (demplot) dan penyuluhan yang lebih intens lagi untuk dapat memberikan inspirasi, kreativitas dan kesadaran berperilaku pertanian ramah lingkungan dan memanfaatkan sumber daya sekitar sebagai pupuk hayati dan biopestisida untuk mengurangi penggunaan pupuk dan pestisida kimia. Beberapa faktor yang berpengaruh terhadap motivasi petani baik secara langsung maupun tidak langsung. Secara langsung, tingkat motivasi dipengaruhi kapasitas petani dan persepsi petani. dan secara tidak langsung oleh faktor karakteristik petani, dan peran penyuluh. Kapasitas petani dalam menerapkan pertanian ramah lingkungan diukur dengan kategori rendah karena belum ditemukan petani organik di Tambun Utara. Persepsi petani merupakan faktor ke-2 yang berpengaruh langsung terhadap motivasi: 1). Rendahnya persepsi petani terhadap pertanian ramah lingkungan disebabkan daya musnah pestisida kimia yang segera dapat mengatasi OPT sehingga mempengaruhi produktivitas pertanian, 2). Biaya transportasi mahal, 3). Harga pupuk organik mahal, 4). Peningkatan hasil padi tidak cepat

\section{Pelatihan Pembuatan Pupuk Organik Dan Biopestisida}

Pelatihan ini dilakukan di halaman kantor Badan Penyuluh Pertanian (BPP) Tambun Utara Tujuan pelatihan pembuatan pupuk organik dan biopestida adalah: 1) untuk mendukung program pemerintah dalam mengembangkan pertanian organik yang ramah lingkungan dengan menggunakan bahan-bahan alami yang ada di sekitar lokasi penyuluhan seperti daun pepaya, bonggol pisang, air beras, air kelapa dan buah nanas, 2) mengenalkan pengetahuan kepada petani tentang pembuatan pupuk organik dan biopestisida dan 3) merubah mindset petani dalam penggunaan pupuk kimia dan pestisida kimia kepada penggunaan pupuk organik dan biopestisida ramah lingkungan sehingga petani mau mengurangi atau meniadakan pupuk dan pestisida kimia.

\section{A. Pembuatan Pupuk Organik}


Bahan yang digunakan untuk pembuatan MOL (Mikroorganisme Lokal) meliputi: bonggol pisang $1 \mathrm{~kg}$, air cucian beras 2 liter, air kelapa 20 liter, gula merah $1,5 \mathrm{~kg}$, dan nanas matang tua 4 buah.

Cara pembuatannya:

a. Bonggol pisang dan nanas dipotong kecil-kecil, dimasukkan bersama air beras, air kelapa dan gula merah ke dalam wadah drum.

b. Campuran tersebut diaduk rata dan disimpan dalam drum plastic

c. Tutup dengan plastik yang rapat dan diberi lubang udara dengan cara memasukkan selang plastik yang dihubungkan dengan botol yang sudah berisi air. Ujung selang plastik harus terendam dalm air dan dibiarkan selama 15 hari.

d. Larutan hasil saringan dapat langsung di aplikasikan dengan cara menyemprotkan larutan ke akar tanaman.

Salah satu pupuk organik cair yang mengandalkan organisme lokal adalah MOL. MOL adalah larutan dari hasil fermentasi yang berasal dari sisa-sisa pembusukan bahan organik yang mudah terurai. Penggunaan MOL mempunyai keuntungan yaitu biaya yang dibutuhkan murah dan cara pembuatannya mudah. Fungsi utama dari MOL antara lain: 1) membantu menyuburkan tanah, 2). Mempercepat proses pengomposan dan 3) Mudah diaplikasikan untuk pemupukan tanaman rumahan. Menurut Maspary (2012) bahwa untuk membuat MOL dibutuhkan 3 bahan utama yaitu :

\section{a. Sumber Bakteri Mikroorganisme Lokal}

Bahan yang digunakan sebagai mikroorganisme adalah bonggol pisang dan nanas. Bonggol pisang mengandung mikroorganisme antara lain Bacillus sp., Aeromonas sp., Aspergillus nigger, Azospirillium, Azotobacter. Pada nanas mengandung mikroorganisme Acetobacter xylinum (Fikania, 2017).

\section{b. Karbohidrat.}

Air cucian beras menyediakan karbohidrat sebagai sumber energi yang dibutuhkan mikroorganisme

\section{c. Glukosa.}

Air gula dan air kelapa mengandung glukosa sebagai sumber energi yang bersifat spontan bagi mikroorganisme

Proses fermentasi mikroorganisme lokal (MOL) terjadi dalam kondisi anaerob atau tidak membutuhkan oksigen sehingga memerlukan media tertutup, seperti: botol plastik atau wadah sisa cat air sebagai media fregmentasi. Hindari wadah yang berbahan dasar logam karena mudah berkarat. Pembuatan mikroorganisme lokal (MOL) membutuhkan waktu lima sampai dua puluh satu hari tergantung pada bahan-bahan yang digunakan (Khalimatu Nisa. et al. 2017).

\section{B. Pembuatan Biopestisida}

Bahan-bahan yang digunakan meliputi: daun papaya $1 \mathrm{~kg}$, air 10 liter, minyak tanah 2 sendok makan, dan deterjen 30 gram.

Cara pembuatannya:

a. Siapkan daun papaya dan dipotong-potong kecil

b. Hasil rajangan daun papaya direndam dalam ember yang berisi 10 liter air

c. Ditambahkan 2 sendok minyak tanah dan 30 gram deterjen 
d. Campuran didiamkan selama 24 jam

e. Larutan hasil perendaman disaring dengan kain halus

f. Cairan hasil saringan langsung dapat di aplikasikan dengan cara menyemprotkan ke permukaan tanaman.

Daun pepaya digunakan sebagai biopestisida karena mengandung enzim sistein protease seperti papain dan kimopapain.

Kandungan senyawa kimia dalam daun pepaya yang dapat mematikan organisme pengganggu adalah senyawa golongan alkalois, terpenoid, flavonoid, dan asam amino nonprotein (Julaily, et al. 2012). Lebih lanjut Kementerian Pertanian (2018) dari biopestisida daun pepaya dapat mengendalikan berbagai jenis ulat, cendawan, mosaic virus, embun tepung, hama dalam tanah, thrips, kutu kebul dan hama-hama pengisap.

Detergen digunakan sebagai biopestisida karena mengandung surfaktan dan linier alkil benzene sulfonate yang bersifat karsinogenik yang dapat membunuh hama. (Kementerian Pertanian, 2018). Minyak tanah digunakan sebagai biopestisida untuk mengusir koloni serangga (Kementerian Pertanian, 2018).

Cara kerja biopestisida adalah merusak perkembangan telur, larva dan pupa, menghambat pergantian kulit, mengganggu komunikasi serangga, menyebabkan serangga menolak makan, menghambat reproduksi serangga betina, mengurangi nafsu makan, memblokir kemampuan makan serangga, mengusir serangga, menghambat perkembangan patogen penyakit (Kementerian Pertanian, 2018).

Berdasarkan kegiatan pelatihan, petani berinspirasi untuk memanfaatkan daun mindi, daun mahoni, buah maja, daun pepahitan, kunyit, daun galam dan lainnya untuk dimanfaatkan sebagai biopestisida.

Materi pelatihan ini berdasarkan literatur dari Bimtek Biopestisida BALINGTAN, Solusi Pencegahan Hama Yang Ramah Lingkungan.yang disampaikan oleh Sri Wahyuni di Bogor pada 4-5 Desember 2018. Suasana kegiatan penyuluhan dan pelatihan disajikan pada Gambar 3.
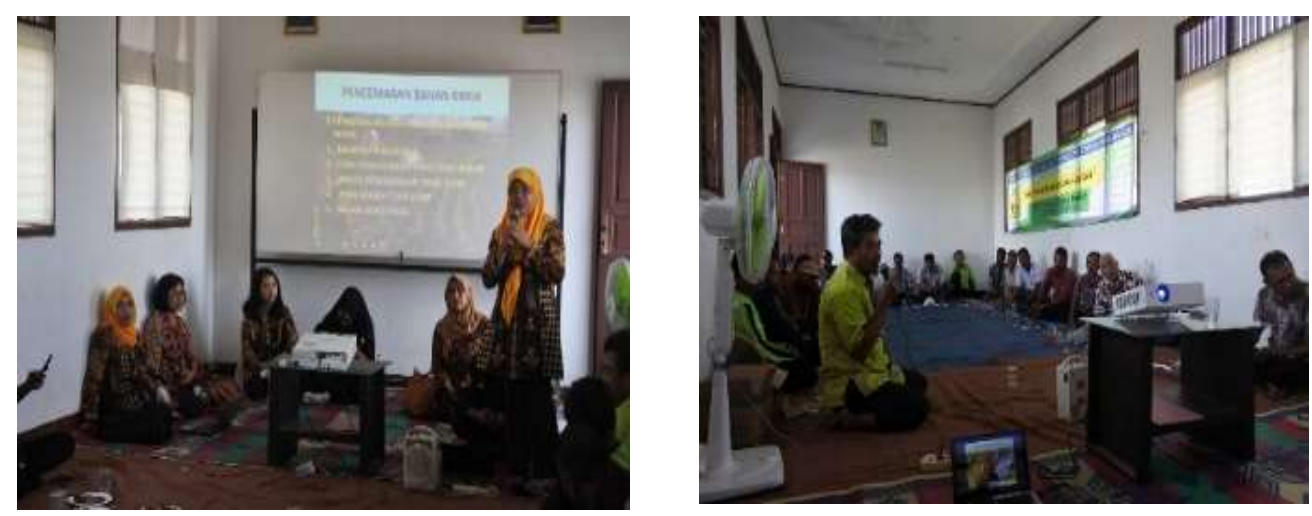


$\begin{array}{ll}\text { ABDI WIRALODRA } & \text { ISSN 2656-5501 (Print) } \\ \text { JURNAL PENGABDIAN KEPADA MASYARAKAT } & \text { ISSN 2714-8041 (Online) }\end{array}$

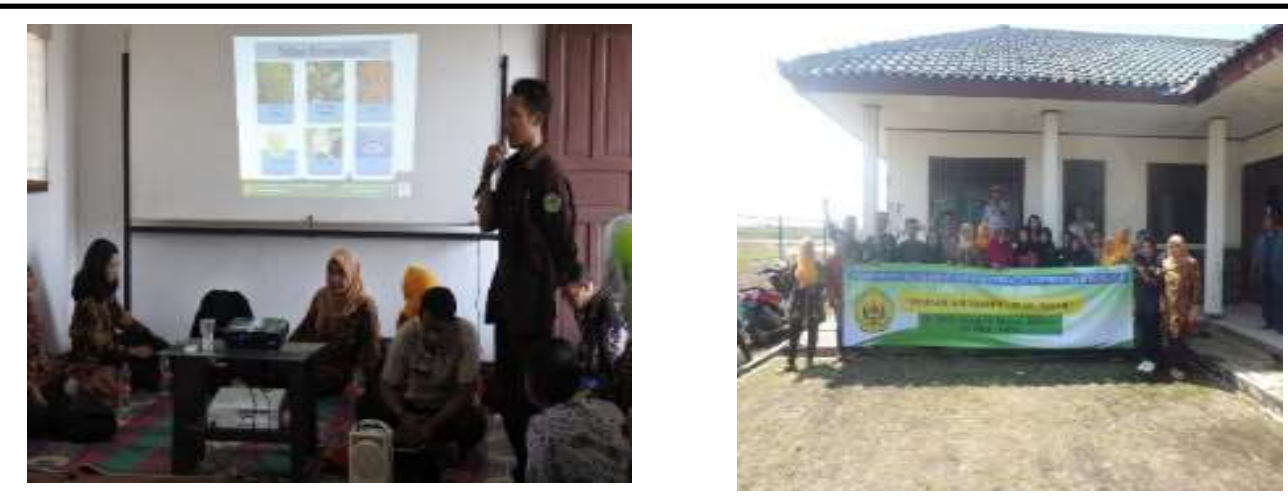

Gambar 3. Kegiatan Penyuluhan dan Pelatihan

\section{D.KESIMPULAN}

1. Penyuluhan telah meningkatkan pengetahuan, sikap dan motivasi petani tentang pertanian ramah lingkungan namun belum cukup untuk bertindak.

2. Pelatihan memberikan pengetahuan dan ketrampilan untuk membuat pupuk organik dan biopestisida, dan memotivasi petani untuk membuat dengan bahan yang ada di sekitar mereka. Pelatihan telah menginspirasi petani untuk kreatif dan berinovasi memanfaatkan sumberdaya sekitar.

\section{E. UCAPAN TERIMA KASIH}

Terselenggaranya kegiatan ini berkat kerjasama dan dukungan berbagai pihak, untuk itu diucapkan terima kasih kepada: 1). Ketua LPPM Universitas Borobudur; 2). Dekan Fakultas Pertanian Universitas Bororbudur, 3). Kepala Desa Srimukti, Kecamatan Tambun Utara, Kabupaten Bekasi, 4). Kepala BPP Tambun Utara, Kabupaten Bekasi.

\section{F. DAFTAR PUSTAKA}

BPS Kabupaten Bekasi. 2019. Kabupaten Bekasi Dalam Angka. Bekasi.

Balingtan, 2018. State of the art on soil pollution and its impact on human. Balai Penelitian Lingkungan Pertanian (Balingtan), Bogor.

Damayanti, et.al. 2017. Metode Pre-Test dan Post-Test Sebagai Salah Satu Alat Ukur Keberhasilan Kegiatan Penyuluhan Kesehatan Tentang Tuberculosis Di Kelurahan Utan Panjang, Jakarta Pusat. Prosiding SNaPP 2017 Kesehatan. Vol. 3, No.1. Hal: 144-150.

Fikania, Deska. 2017. Pengaruh Perbandingan Buah Nanas Madu Dengan Sukrosa Dan Suhu Inkubasi Terhadap Karakteristik Starter Alami Nanas Madu (Ananas Cosmosus L). Skripsi. Universitas Pasundan. Bandung.

Julaily, Noorbetha., Mukarlina., dan Tri, R. Setyawati. 2013. Pengendalian Hama Pada Tanaman Sawi (Brassica juncea L.) Menggunakan Ekstrak Daun Papaya (Carica papaya L.). Jurnal Protobiont. Program Studi Biologi. Fakultas MIPA. Universitas Tanjungpura. Diakses melalui http://jurnal.untan.ac.id.

Kementerian Pertanian. 2015. Atlas: Peta Pengembangan Kawasan Padi Kabupaten Bekasi, Provinsi Jawa Barat. Diunduh pada tanggal 10 September 2019. Dari: www1.pertanian.go.id/sikp/files/pjku50/CETAK_BEKASI_FINAL.pdf. 
Kementerian Pertanian. 2018. Pembuatan Pestisida Alami Dari Daun Papaya. Direktorat Perlindungan Hortikultura. Diunduh tanggal 11 September 2019. http://ditlin.hortikultura.pertanian.go.id/index.php?option=com_content\&vie $\mathrm{w}=$ article $\& \mathrm{id}=349$ :pestisida-alami-dari-daun-pepaya\&catid=58:g

Khalimatu, Nisa., et.al. 2017. Buku Pintar Membuat Pupuk Kompos dan MOL. Dari:

https://books.google.co.id/books?hl=id\&lr=\&id=ZFDOCgAAQBAJ\&oi=fn $\mathrm{d} \& \mathrm{pg}=\mathrm{PA} 1 \& \mathrm{dq}=$ penelitian+pestisida+kimia\&ots=SloEnn3bSQ\&sig=R0QJ OtoS7XINoFp1nPndSIO84uQ\&r.

Maharani, R Belinda, Tini Surtiningsih, Edy Setiti Wida Utami. 2013. Pengaruh Pemberian Pupuk Hayati (Biofertilizer) Dan Media Tanam Terhadap Pertumbuhan Dan Produksi Tanaman Tomat (Lycopersicum esculentum Mill.). Program Studi S1 Biologi, Departemen Biologi, Fakultas Sains Dan Teknologi, Universitas Airlangga, Surabaya.

Mamaril, C.P., M.B. Castillo and L.S. Sebastian. 2009. Facts and myths about organic fertilizers. Philippine Rice Research Institute (PhilRice). Science City of Munoz. Nueva Ecija.Philippnes.

Maspary. 2012. 3 Bahan Utama Pembuat MOL. Gerbang Pertanian. Diunduh tanggal 17 September 2019. Dari:

http://www.gerbangpertanian.com/2012/04/3-bahan-utama-pembuatanmol.html.

Ningrum, Tri Kusuma.2012. Survei Evaluasi Program Pemasyarakatan Pengendalian Hama Terpadu (PHT) Petani Padi di Kecamatan Tambun Utara, Bekasi. Departemen Proteksi Fakultas Pertanian. Institut Pertanian Bogor. Bogor.

Suyamto. 2017. Manfaat Bahan dan Pupuk Organik pada Tanaman Padi di Lahan Padi Sawah Irigasi. Balai Pengkajian Teknologi Pertanian Jawa Timur. $\begin{array}{lllll}\text { Diunduh } & \text { tanggal } & 10 & \text { setember } & 2019\end{array}$ file:///C:/Users/Asus/Downloads/8179-21692-1-SM.pdf..

Wahyuni, Sri. 2018. Solusi Pencegahan Hama Yang Ramah Lingkungan. BIMTEK Biopestisida BALINGTAN Pada 4-5 Desember 2018. Balai Penelitian Lingkungan Pertanian (BALINGTAN). Bogor. 